\title{
A study of cement additive from varied heating temperature of coconut shell charcoal to increase cement strength
}

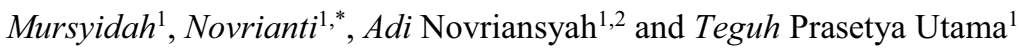 \\ ${ }^{1}$ Petroleum Department, Faculty of Engineering, Islamic University of Riau, 28284, Indonesia \\ 2 Department of Energy and Mineral Resources Engineering, Sejong University, Republic of Korea
}

\begin{abstract}
This experimental study introduces an organic wasted material, which hopefully can be another solution besides other expensive chemical-based additives. The study intends to investigate the effect heating temperature on charcoal powder, which is originated from the coconut-shell waste material, related to its ability in enhancing cement strength. Six samples with different additive concentration should be prepared before initiating the strength test. the strength test principally follows the bi-axial loading test procedure, where each sample will be burdened by a certain amount of the load force until failure condition was reached. The recorded pressure where the failure occurs will be treated as maximum load, which is needed for determining compressive strength and shear-bond-strength values. Those parameters should be in refer to respectable standard in the oil and gas industry. Results from the strength test clearly indicate that higher heating temperature yields to a cement with a high strength. The optimal heating temperature has reached for a sample with $700^{\circ} \mathrm{C}$ charcoal powder. It is a potential opportunity in increasing the economic value of the waste material.
\end{abstract}

\section{Introduction}

Well-cementing operation is one of the important aspects of oil and gas drilling activity [1]. The successful cementing job can prolong the oil-well lifetime, which can reduce the workover job frequency. The purpose of the well cementing operation is to adhere the casing into the formation, protected from the mechanical problem such as vibration, prevent from direct contact with the corrosive fluid, and to separate each zone behind it [2]. Failure in cementing operation will bring a serious problem in the hydrocarbon production stage. Therefore, ensuring a good quality cement bond is a serious task.

Wellbore environment leads to a precise effort in designing a cement composition to construct a proper concrete. Such properties shall be considered are fluid loss rate, Waiting-On-Cement (WOC) time, density, and its strength. Those properties can be altered by introducing the additive into the cement slurry without lowering its bond quality [3].

A good quality bonding of cement can be determined from the compressive strength (CS) and shear bond strength (SBS) parameter. CS defines as the ability of cement to resist a geological force from the formation while SBS describes the ability of the cement to bear a vertical force due casing string weight. Cement should have a certain amount of CS and SBS values where cement is strong enough to withstand a casing from the formation pressure. In oil and gas industry, the cement strength should refer to the standard from American Petroleum Institute (API).
Various studies have been conducted to improve the cement bond quality by attaching chemical additives. The compressive strength of the cement can be enhanced by adding pozzolanic material. Moreover, a chemical additive such as silicon oxide $\left(\mathrm{SiO}_{2}\right)$, Iron Oxide $\left(\mathrm{Fe}_{2} \mathrm{O}_{3}\right)$ and Aluminum oxide $\left(\mathrm{Al}_{2} \mathrm{O}_{3}\right)$ are effective additives to accomplish this purpose [4]. Although many studies have proven the effectiveness of chemical additive in enhancing the strength of cement, it will need an extra cost and it will affect the project viability. A low-cost material will be required for a more viable cementing operation.

Our experimental study aims to an introduction of coconut shell charcoal, we called Coconut Shell Carbon (CSC), as an additive to cement. The raw material of $\mathrm{CSC}$ can be found easily in Indonesia. With approximately $3.8 \mathrm{Ha}$, plantation site and produce almost 17 billion coconuts per year, Indonesia is a potential spot for developing this additive. Coconut shell is an organic material which is mostly enriched by carbon-based compounds such as cellulose, lignin, and pentose [5]. The process where the carbon was formed occurs via direct and indirect heating to the carbon-based material. The heating process can be completed in burial-klinoven, and in open space. The minimum requirement for heating process temperature is $500^{\circ} \mathrm{C}$. Works by Basuki in 2008 [6] have confirmed that CSC contains metal ions and water molecule at room condition. If CSC is exposed to heat and the temperature increase up to $100^{\circ} \mathrm{C}$, the water molecule will vaporize and CSC turns out as fluid (liquid or gas) absorber. Experiment by Hawley [7]

* Corresponding author: adinovriansyah $@$ eng.uir.ac.id 
indicated that charcoal purification and tar creation occur and continue when the temperature reaches $500^{\circ} \mathrm{C}$.

Less experimental studies have been investigated the effect of heating temperature to CS and SBS parameter. Work by Novriansyah [8] has approved that CSC additive can enhance cement strength. However, his works utilize CSC-Nanosilica in nanocomposite form and did not inspect the temperature effect. Thus, through this experimental study, we research the effect of heating temperature of CSC to $\mathrm{CS}$ and SBS parameter. An optimal heating temperature, a temperature where CSC additive yields the highest CS and SBS, can be obtained. A treatment to produce a representative CSC additive for oil-well cementing will be available.

\section{Experimental Design}

This experimental study use type-G Portland cement according to API standards (article 10A) [10]. Moreover, CSC in chunks form was purchased from the local industry in Pekanbaru, Indonesia. To attain the powder form of CSC, the chunks should be ground to crack it into a fine form. The fine form of CSC then is sieved with a certain size (in this case, 200 mesh) to ensure all CSC in uniform size. To observe the effect of CSC heating temperature to $\mathrm{CS}$ and SBS, each sample should be heated (in this case, the temperature range is $400^{\circ} \mathrm{C}$ to $900^{\circ} \mathrm{C}$ with $100^{\circ} \mathrm{C}$ escalation) by using oven furnace. The physical properties and the chemical composition of CS are listed in Table 1 and Table 2 respectively. From the table 2, The CSC Sample is dominantly composed of $\mathrm{SiO}_{2}$ mineral, pozzolanic material which is commonly found in sandstone formation, a place where the hydrocarbon was accumulated.

Table 1. Physical Properties of CSC

\begin{tabular}{|c|c|}
\hline $\begin{array}{c}\text { Physical } \\
\text { Properties }\end{array}$ & $\begin{array}{c}\text { Value and } \\
\text { Explanation }\end{array}$ \\
\hline Color & Black \\
\hline Specific Gravity & 1.12 \\
\hline Density & $0.208 \mathrm{gr} . \mathrm{cm}^{3}$ \\
\hline Ash Concentration & $10 \%$ \\
\hline Specific Heat & $1 \mathrm{~J} / \mathrm{g}^{\circ} \mathrm{C}$ \\
\hline $\begin{array}{c}\text { Thermal } \\
\text { Conductivity }\end{array}$ & $0.2 \mathrm{~W} /(\mathrm{mK})$ \\
\hline Moisture Content & $4 \%$ \\
\hline
\end{tabular}

A hydraulic press apparatus should be prepared to conduct a biaxial loading test. This apparatus consists of a hydraulic pump which is connected to the removable steel plate. The hydraulic air pump supplies a hydraulic force which can push the steel plate. A pressure gauge is installed to apparatus for pressure reading.
Table 2. Chemical composition of CSC

\begin{tabular}{|c|c|}
\hline Chemical Compound & Content (\%) \\
\hline $\mathrm{MgO}$ & 2.5 \\
\hline $\mathrm{Al}_{2} \mathrm{O}_{3}$ & 1.2 \\
\hline $\mathrm{SiO}_{2}$ & 45.07 \\
\hline $\mathrm{P}_{2} \mathrm{O}_{5}$ & 9.77 \\
\hline $\mathrm{SO} 3$ & 3.12 \\
\hline $\mathrm{C}$ & 4.96 \\
\hline $\mathrm{K}_{2} \mathrm{O}$ & 6.59 \\
\hline $\mathrm{CaO} \mathrm{O}$ & 24.2 \\
\hline $\mathrm{Cr}_{2} \mathrm{O}_{3}$ & 0.27 \\
\hline $\mathrm{Fe}_{2} \mathrm{O}_{3}$ & 1.8 \\
\hline $\mathrm{CuO}_{2 n O}$ & 0.27 \\
\hline $\mathrm{ZnO}_{2} \mathrm{O}$ & 0.13 \\
\hline $\mathrm{Rb}_{2} \mathrm{O}$ & 0.12 \\
\hline
\end{tabular}

\subsection{Material and Apparatus}

CS and SBS value are obtained from biaxial loading test by using hydraulic press apparatus. Various samples based on the cement compositions (see Table 3) should be prepared before the initiating the loading test. All needed material such as cement powder, de-ionized water, CSC powder and supporting additive were blended together by using a high-speed propeller mixer. The utilization of de-ionized water in the experimental study is due to verify that no chemical interaction between ion in water and other material. The mixer is set at a constant speed (4000 RPM) for 20 seconds before pouring all of the ingredients. The speed then is reduced 1200 RPM for 4 minutes until the homogeneous blends. Each sample is poured into the mold and dried at room condition for 24 hours to confirm all the samples are free from water. Sample cement show at figure 1 and the size of the sample at table 3 .

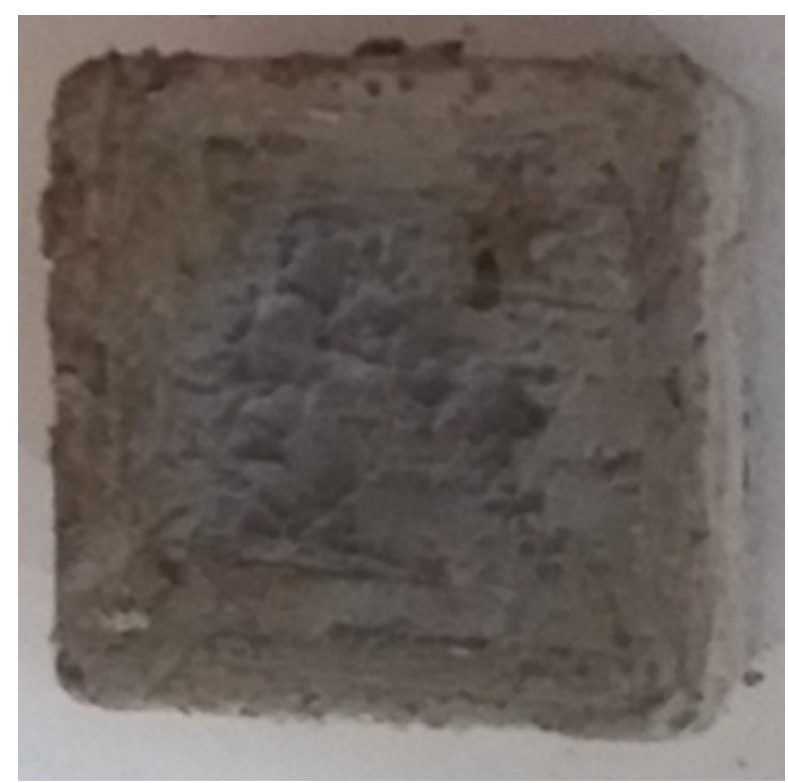

Fig.1. Sample Cement 
Table 3. Cement Sample Dimension

\begin{tabular}{|c|c|c|c|}
\hline Temperature $\left({ }^{\circ} \mathrm{C}\right)$ & $\begin{array}{c}\text { Length } \\
(\mathrm{cm})\end{array}$ & $\begin{array}{c}\text { Width } \\
(\mathrm{cm})\end{array}$ & $\begin{array}{c}\text { Height } \\
(\mathrm{Cm})\end{array}$ \\
\hline $400^{\circ} \mathrm{C}$ & 5.14 & 5.1 & 4.7 \\
\hline $500^{\circ} \mathrm{C}$ & 5.14 & 5.02 & 4.7 \\
\hline $600^{\circ} \mathrm{C}$ & 5.125 & 5.1 & 4.63 \\
\hline $700^{\circ} \mathrm{C}$ & 5.13 & 5.04 & 4.42 \\
\hline $800^{\circ} \mathrm{C}$ & 5.13 & 5.025 & 4.84 \\
\hline $900^{\circ} \mathrm{C}$ & 5.12 & 5.1 & 4.54 \\
\hline
\end{tabular}

Before conducting the biaxial loading test, all of the samples should be removed from the mold after the drying process is completed. A hydraulic press apparatus should be ensured at the standard condition to prevent the error reading when the test is being performed. A certain amount of load will be imposed to the sample by applying pressure from the hydraulic air pump. The pressured air will push the steel plate downwards, and the sample will be compressed until the condition where the failure was achieved. The compressive strength and shear bond strength of the sample can be calculated by dividing the recorded load from the pressure gauge with the sample's cross-sectional area. A Sequential analysis consisting the Scanning electron microscope (SEM) to image the effect of the nanocomposite on cement surface structure, energy dispersive X-ray spectroscopy (EDX) to quantify the chemical compound of cement, and XRay Diffraction (XRD) measurements were performed for each slurry sample.

\section{Result and discussion}

Figure 2 and 3 depicts the plot of CS and SBS for each sample respectively. It is clearly shown in Figure 1 and 2 that CS and SBS indicates a respectable value for oilwell cementing, according to the API standard (article 10A). An increment trend of CS has been revealed when the heating temperature is going up. The CS value rises to around $1675 \mathrm{psi}$ when the heating temperature increased up to $700^{\circ} \mathrm{C}$ (more than $80 \%$ increment, compare to the sample with $400^{\circ} \mathrm{C}$ heating temperature.A similar phenomenon occurs when investigating the effect of heating temperature on SBS value. The highest SBS value is achieved for the sample with CSC temperature is $700^{\circ} \mathrm{C}$, where the increment reaches $100 \%$, compare to the sample with the lowest SBS value in the experiment.

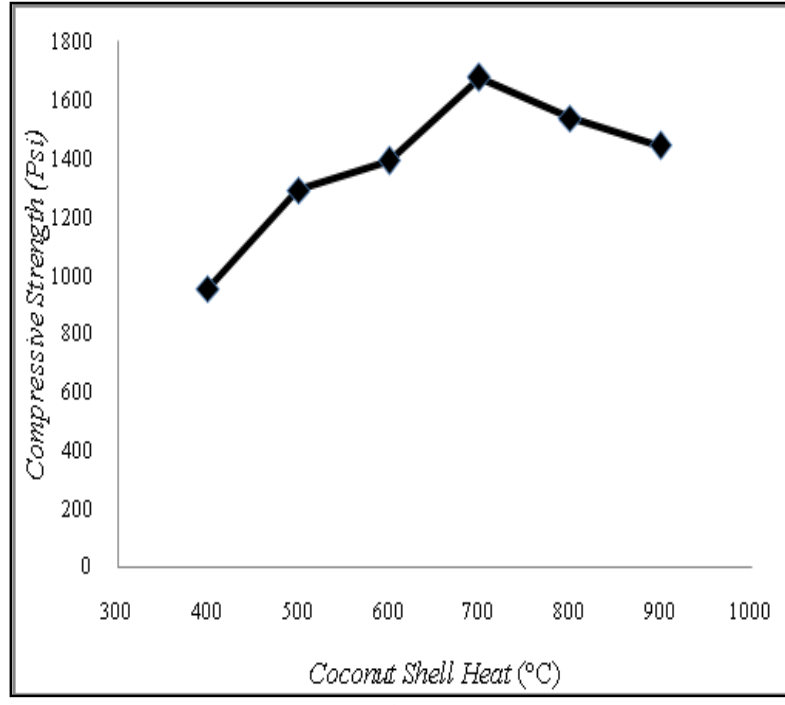

Fig.2. Compressive Strength vs CSC Temperature

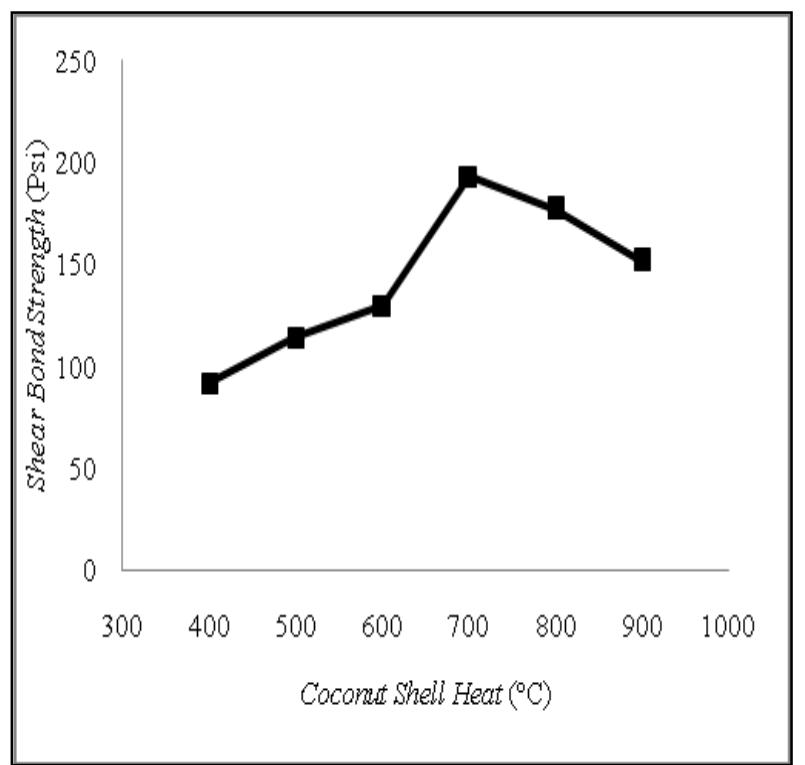

Fig.3. Shear Bond strength vs CSC Temperature

This experimental study has efficaciously proven the effectiveness of CSC additive to enhance the cement strength. Results from the experiment are consistent with Hawley experiment where the CSC undergoes a charcoal purification when the temperature more than $500^{\circ} \mathrm{C}$. The $\mathrm{CS}$ and SBS are reduced if the heating temperature is higher than $700^{\circ} \mathrm{C}$. This is due to the existence of hydrogen gas in the CSC. It reduces the bonding force between cement and CSC. The result from the XRD measurement is displayed in figure 4 for $\mathrm{S} 4$ sample. By applying crystal interpellation, the crystal content in the sample with $700^{\circ} \mathrm{C}$ additive is approximately $66 \%$. Higher crystal content will enhance the inter-particle bonding of cement. The Imaging process from SEM Analysis has demonstrated that cement and CSC have uniformly bonded and distributed (see the blue circle). The result from the SEM measurement is displayed in figure 5 for S4 sample. 


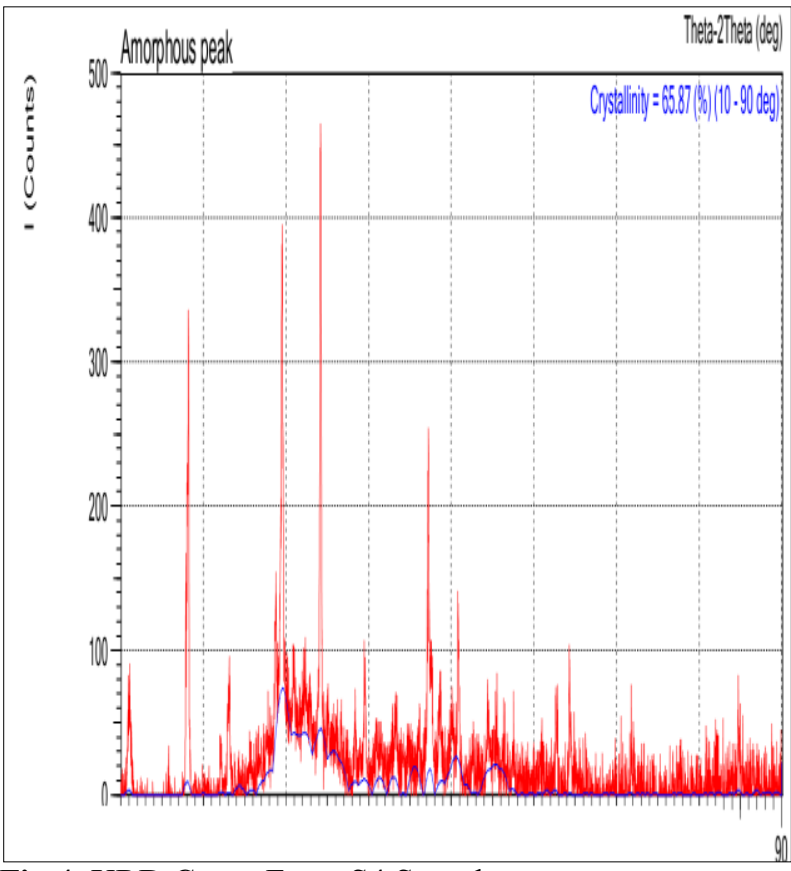

Fig.4. XRD Curve From S4 Sample

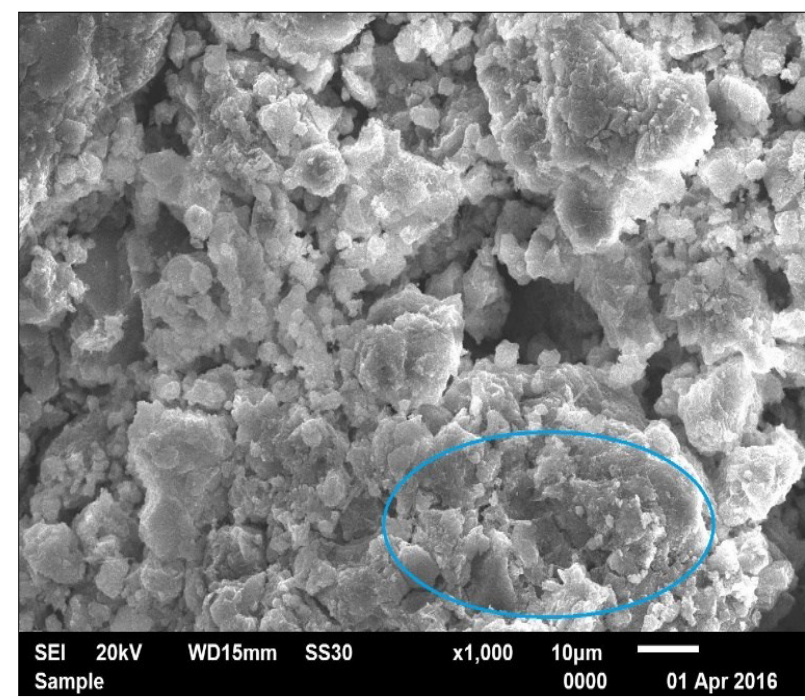

Fig.5. Surface Structure from S4 Sample

Comparing the chemical composition of the cement sample (Table 4) has shown that CSC additive can increase silica and aluminum content in the cement. The silica content has shown $113 \%$ incremental in form of $\mathrm{SiO}_{2}$. The similar phenomenon occurs for Aluminum where the content increases up to $90 \%$ in the form of $\mathrm{Al}_{2} \mathrm{O}_{3}$. Other chemical compounds in oxide form show the same trend with the mentioned compound before. However, the contribution is not significant due to the minor content in the cement sample. Nevertheless, the existence of the free oxygen in the cement is not detected in the sample with CSC additive. It is possible because all of the free oxygen will react with those reactive chemical group additive to form an oxide-based compound. Moreover, this existence of the oxide compound can enhance the inter-particle bond of the cement, resulting in a cement with higher strength.
Table 4. Chemical compounds in cement slurry

\begin{tabular}{|c|c|c|c|c|c|}
\hline $\begin{array}{c}\text { Ele } \\
\text { me } \\
\mathbf{n t}\end{array}$ & $\begin{array}{c}\text { Com } \\
\text { pound } \\
\text { Mass } \\
\mathbf{( \% )}\end{array}$ & $\begin{array}{c}\text { Mol } \\
\mathbf{( \% )}\end{array}$ & $\begin{array}{c}\text { Com } \\
\text { pound }\end{array}$ & $\begin{array}{c}\text { Com } \\
\text { pound } \\
\text { Mass } \\
\mathbf{( \% )}\end{array}$ & $\begin{array}{c}\text { Ca } \\
\text { tion }\end{array}$ \\
\hline $\mathrm{C}$ & 22,06 & 56,88 & $\mathrm{C}$ & 22,06 & 0 \\
\hline $\mathrm{O}$ & 28,38 & - & - & - & - \\
\hline $\mathrm{Mg}$ & 0,73 & 0,97 & $\mathrm{MgO}^{\prime}$ & 1,21 & 0,39 \\
\hline $\mathrm{Al}$ & 2,22 & 1,33 & $\mathrm{Al}_{2} \mathrm{O}_{3}$ & 4,19 & 1,07 \\
\hline $\mathrm{Si}$ & 10,35 & 11,95 & $\mathrm{SiO}_{2}$ & 22,13 & 4,81 \\
\hline $\mathrm{S}$ & 1,02 & 1,04 & $\mathrm{SO}_{3}$ & 2,56 & 0,42 \\
\hline $\mathrm{Cl}$ & 0,45 & 0,42 & $\mathrm{Cl}$ & 0,45 & 0 \\
\hline $\mathrm{K}$ & 0,74 & 0,31 & $\mathrm{~K}_{2} \mathrm{O}$ & 0,89 & 0,25 \\
\hline $\mathrm{Ca}$ & 31,90 & 25,82 & $\mathrm{CaO}$ & 44,63 & 10,40 \\
\hline $\mathrm{Ti}$ & 0,27 & 0,18 & $\mathrm{TiO}_{2}$ & 0,45 & 0,07 \\
\hline $\mathrm{Fe}$ & 1,89 & 1,1 & $\mathrm{FeO}$ & 2,43 & 0,44 \\
\hline $\mathbf{T o t}$ & $\mathbf{1 0 0}$ & $\mathbf{1 0 0}$ & $\mathbf{T o t a l}$ & $\mathbf{1 0 0}$ & $\mathbf{1 7 , 8 6}$ \\
$\mathbf{a l}$ & & & & & \\
\hline
\end{tabular}

\section{Conclusion}

In this study, the charcoal form of the coconut shell has been implemented to enhance the cement strength. Several experiments have been conducted to obtain a representative combination of compressive strength and shear bond strength value. From the experiments, the optimum concentration of coconut shell carbon with $700^{\circ} \mathrm{C}$ charcoal combustion temperature respectively. Comparison from XRD test, the crystallization value is around $66 \%$. The coconut shell carbon with $700^{\circ} \mathrm{C}$ charcoal combustion temperature will yield the highest compressive strength value (1676.433 psi) and 192.876 psi for shear bond strength value. Comparison from SEM the cement and CSC have uniformly bonded and distributed.

\section{References}

[1] V. Ershadi., et al. J. Environ. Sci. Develop 2: 128132 (2011).

[2] A.T Burgoyne, Applied Drilling Engineering, SPE, USA, (1986).

[3] E. B. Nelson, (Ed).Well cementing. Newnes. (1990)

[4] A. Buntoro \& R. Rubiandini. Proceeding of The $5^{\text {th }}$ Inaga Annual Scientific Conference And Exhibition Yogyakarta(2001).

[5] K.A Widiatama , L. Nuriyah L., D.J. Djoko Herry Santojo., Istiroyah., Masruroh. results.ipi.191833.

[6] K.T. Basuki, Setiawan Budi, Seminar Nasional IV SDM Teknology Nuklir, Yogyakarta (25-26 Agustus 2008). 
[7] A. Novriansyah, Mursyidah, S.S.A Putri, Novrianti, and W.S. Bae. IJAMCE Vol.3, Issue-2 : 58-61 (2016)

[8] API, RP. 10A. Specification for Cements and Materials for Well Cementing. Twenty- (2002)

[9] Backe, K. R., O. B. Lile, and S. K. Lyomov. Society of Petroleum Engineers (1998)

[10] Kazemian, Sina, Bujang BK Huat, and Maassoumeh Barghchi. Int. J. Phys. Sci 6.4: 707-713. (2011)

[11] Kakumoto Masayo, Yoneda Jon, Tenma Nario, Miyazaki Kuniyuki, Aoki Kazuo. Proceeding of the twenty second Intrnational Offshore and Polar Engineering Conference Rhodes, Greece, June 1722, 77-82 (2002)

[12] Pradipta Imam,. Annual Convention And Exhibition, Indonesian Petroleum Association (2010)

[13] Subhash N. Shah, Ph.D., P.E., Narayan H. Shanker, and Chinenye C. OgugbueWell Construction Technology Center. University of Oklahoma. (2010)

[14] Rubiandini Rudi. New Additive for Improving Shearbond Strenght in High Temperature and Presure cement. IADC/SPE 62750. 1-18

[15] Rubiandini Rudi, Siregar Septoratno, Nursuharcahyo, Efrial Deny. Proc. ITB eng science Vol 37B NO.1 :29-48. (2005)

[16]Ridha, Syahrir, Sonny Irawan, and Bambang Ariwahjoedi. Journal of Petroleum Exploration and Production Technology 3.4 :303-311.(2013)

[17] Widjaja A.P, Darjo, S. Making charcoal active with dry destilation II. Komunikasi Balai Penelitian Kimia Bogor. (1980) 